\title{
FAKTOR RISIKO ANEMIA PADA SISWI PESERTA PROGRAM SUPLEMENTASI
}

\author{
(Risk Factors of Anemia in School Girls Participant of Supplementation Program)
}

\author{
Dodik Briawan ${ }^{1 *}$, Ermita Arumsari ${ }^{2}$, dan Pusporini ${ }^{3}$
}

1 Departemen Gizi Masyarakat, Fakultas Ekologi Manusia, Institut Pertanian Bogor, Bogor 16680.
2 PT Indocater JSNO, Jl. Ketel Uap PLTU, Kalijapat III, Tanjung Priok Jakarta Utara.
3 Seksi Kesehatan Keluarga Dinas Kesehatan Kota Bekasi, Jl. Jenderal Sudirman No.3 Kota Bekasi.
* Alamat korespondensi: Departemen Gizi Masyarakat, Fakultas Ekologi Manusia, Institut Pertanian
Bogor, Bogor 16680. Telp: 0251-8621258; Fax: 0251-8622276; Email: dbriawan@yahoo.com

\begin{abstract}
The aim of study was to analized the risk factors of anemia among school girls participant of supplementation program. Design of this study wass cross-sectional covering 400 secondary and high school students (SMP and SMK) in Bekasi. The secondary data were analized from the baseline program of the Health Office of Bekasi. The prevalence of anemia among school girls was 38.3 percents. The significant risk factors of anemia among school girls were the age and nutritional status (IMT). The anemia risk was higher among school girls at age 13-15 years $(O R=2.73)$ and the thin girls $(O R=8.32)$.
\end{abstract}

Key words: risk factors, anemia, school girls

\section{PENDAHULUAN}

Selama ini anemia merupakan masalah kesehatan masyarakat yang secara global banyak ditemukan di berbagai negara maju maupun sedang berkembang. Penderita anemia diperkirakan hampir dua milyar atau 30\% dari populasi dunia. Prevalensi anemia di Indonesia masih cukup tinggi, yaitu pada remaja wanita $26.50 \%$, wanita usia subur (WUS) $26.9 \%$, ibu hamil $40.1 \%$ dan anak balita $47.0 \%$ (Depkes, 2008).

Remaja wanita merupakan kelompok rawan penderita anemia. Salah satu program yang direkomendasikan WHO sejak awal tahun 1970-an adalah suplementasi besi-folat, dan telah dilakukan di berbagai negara, termasuk Indonesia. Namun demikian perkembangan penurunan prevalensi anemia masih dinilai sangat lambat, yang ditunjukkan oleh rendahnya penurunan angka prevalensi anemia tersebut (WHO, 2004).

Kebutuhan zat besi untuk remaja wanita ditentukan oleh kehilangan basal zat besi di dalam dan di luar tubuh, kehilangan saat menstruasi, dan untuk pertumbuhan (Hallberg, 2001). Kebanyakan remaja yang mempunyai status gizi besi rendah disebabkan oleh kebiasaan kualitas konsumsi pangannya rendah. Remaja wanita sering menderita anemia dikarenakan lebih banyak mengkonsumsi makanan nabati dibandingkan hewani, lebih sering melakukan diit karena ingin langsing, dan mengalami haid setiap bulan (Depkes, 2001). Selain itu juga terjadi pada kelompok yang kehilang- an zat besinya cukup tinggi, yaitu periode yang panjang dan banyak kehilangan darah saat menstruasi, sering melakukan donor darah, dan olah raga yang sangat intensif (Krummel \& Kris-Etherton, 1996). Penyebab anemia lainnya adalah terjadinya kehilangan zat besi karena penyakit infeksi seperti malaria dan cacing (WHO, 2004).

Dampak anemia gizi besi pada remaja adalah menurunkan produktivitas kerja dan juga akan menurunkan kemampuan akademis di sekolah (Beard, 2001; INACG, 2004). Studi Haltermen et al. (2001) pada 5398 anak usia 616 tahun di USA menunjukkan bahwa nilai matematika lebih rendah pada mereka yang defisit besi (anemia dan non-anemia) dibandingkan yang normal. Anak-anak yang defisit besi (anemia dan non-anemia) mempunyai risiko 2.3-2.4 kali dibandingkan anak normal, untuk memperoleh nilai matematika dibawah ratarata. Untuk itu program perbaikan gizi besi pada anak sekolah sangat diperlukan karena tidak hanya mengatasi masalah kesehatan masyarakat tetapi sekaligus peningkatan kualitas pendidikan.

Hasil studi faktor risiko anemia menunjukkan faktor-faktor yang berpengaruh terhadap kejadian anemia antara lain pendidikan, jenis kelamin, wilayah, kebiasaan sarapan, status kesehatan, dan keadaan Indeks Massa Tubuh dalam kategori kurus (Permaesih dan Herman, 2005). Adanya faktor risiko tersebut dapat mempengaruhi kecenderungan status anemia seseorang terutama remaja yang berada dalam masa pertumbuhan. 
Mengingat dampak yang terjadi akibat anemia sangat merugikan tersebut, maka peneliti tertarik untuk mengetahui faktor risiko anemia tersebut pada remaja. Tujuan studi adalah mengkaji faktor risiko anemia remaja putri peserta program Pencegahan dan Penanggulangan Anemia Gizi Besi (PPAGB) di Kota Bekasi.

\section{METODE}

\section{Desain, Tempat, dan Waktu}

Desain penelitian adalah cross-sectional study yaitu baseline data dari Dinas Kesehatan Kota Bekasi untuk pelaksanaan program Pencegahan dan Penanggulangan Anemia Gizi Besi (PPAGB) pada remaja putri di Kota Bekasi. Lokasi penelitian dilaksanakan di dua sekolah yaitu SMP VII dan SMK Teratai Putih Global 2 Kota Bekasi. Pemilihan SMP dan SMK tersebut didasarkan pada kesediaan pihak sekolah untuk mengikuti program, serta tingkat aktifitas Puskesmas yang terdekat dengan lokasi. Waktu pengambilan data dilakukan pada bulan November 2007 sampai Februari 2008.

\section{Penarikan Contoh}

Contoh dalam penelitian ini terdiri dari 200 orang siswi SMP VII dan 200 orang SMK Teratai Putih Global 2 Kota Bekasi. Siswi kelas 1 dan kelas 2 (usia 10-18 tahun) dipilih secara sukarela dan diperoleh jumlah total contoh sebanyak 400 orang.

\section{Jenis dan Cara Pengumpulan Data}

Data yang dianalisis berasal dari baseline data Dinas Kesehatan Kota Bekasi sebagai pelaksana program Pencegahan dan Penanggulangan Anemia Gizi Besi (PPAGB) untuk siswi SMP dan SMA di Kota Bekasi. Data dikumpulkan oleh petugas Puskesmas dan Dinas Kesehatan Bekasi.

Pengumpulan data melalui wawancara dengan menggunakan kuisioner yang meliputi usia, aktivitas fisik, pola menstruasi, riwayat penyakit, Perilaku Hidup Bersih dan Sehat (PHBS), dan perilaku makan. Data frekuensi konsumsi pangan diperoleh dengan metode Food Frequency Questionnaires (FFQ) selama satu minggu terhadap pangan sumber Fe. Data antropometri dan status gizi diukur langsung untuk berat dan tinggi badan dengan alat ukur timbangan injak dan mikrotoise. Kadar hemoglobin dilakukan dengan mengambil sampel da- rah oleh petugas Puskesmas dan dianalisis dengan metode cyanmethemoglobin.

\section{Pengolahan dan Analisis Data}

Status anemia ditentukan berdasarkan kadar hemoglobin yaitu dengan kategori anemia $(\mathrm{Hb}<12 \mathrm{~g} / \mathrm{dl})$ dan tidak anemia $(\mathrm{Hb} \geq 12$ $\mathrm{g} / \mathrm{dl})$. Penggolongan jenis anemia menjadi ringan (10-11.9 g/dl), sedang (7-9.9 g/dl), dan berat (kadar $\mathrm{Hb}<7 \mathrm{~g} / \mathrm{dl}$ ). Data status antropometri Indeks Massa Tubuh (IMT) dengan kategori kurus (IMT < 18.5), normal (IMT 18.5 24.9), risiko untuk gemuk (IMT 25.0 - 26.9), dan gemuk (IMT > 26.9).

Menstruasi didefinisikan sebagai suatu proses fisiologis yang ditandai dengan perdarahan secara periodik dan siklik. Contoh yang sudah mengalami menstruasi diberi skor 1 dan belum menstruasi skor 0 . Frekuensi menstruasi dikategorikan menjadi rendah (2-3 bulan sekali), normal (sebulan sekali), dan tinggi (2 kali sebulan). Banyaknya menstruasi dikategorikan berdasarkan banyaknya pembalut yang digunakan setiap hari yaitu ganti 1-2 kali, 3-4 kali, 56 kali, dan > 6 kali. Lama menstruasi dikategorikan menjadi rendah (<3 hari), normal (3-7 hari), dan tinggi ( $>7$ hari).

Riwayat penyakit dikategorikan sebagai ada tidaknya penyakit yang pernah diderita selama sebulan terakhir yang berhubungan dengan anemia (tuberculosis, malaria, dan keluar cacing). Aktivitas fisik merupakan kegiatan sehari-hari selain belajar. Aktivitas fisik dikategorikan menjadi tiga yaitu : (1) Olahraga ringan seperti jalan santai, lempar cakram, tolak peluru, senam pernapasan, (2) Olahraga sedang seperti basket, voli, lari, senam aerobik, jalan cepat, dan (3) Olahraga berat seperti sepakbola, lari cepat $>10 \mathrm{~km}$, senam aerobik high impact.

Data frekuensi pangan yang dikonsumsi selama seminggu dibagi menjadi lauk hewani, lauk nabati, sayuran, buah-buahan, makanan jajanan, minuman, dan suplemen. Bahan pangan tersebut kemudian dikategorikan menurut frekuensi konsumsinya selama seminggu yaitu tidak pernah, jarang (kurang dari 3 kali), kadang-kadang (3-6 kali), dan setiap hari.

Analisis korelasi Spearman dilakukan untuk menguji signifikansi hubungan antara variabel independen dengan status anemia. Analisis regresi logistik dilakukan untuk mengetahui faktor risiko yang signifikan dengan status anemia. Variabel faktor risiko yang dimasukkan dalam analisis regresi adalah yang signifikan dari analisis korelasi dengan status anemia. 


\section{HASIL DAN PEMBAHASAN}

\section{Status Anemia}

Status anemia ditentukan berdasarkan kadar hemoglobin darah. Konsentrasi hemoglobin contoh berkisar antara 7.2 hingga $16.0 \mathrm{~g} / \mathrm{dl}$ atau rata-rata $12.4 \pm 1.5 \mathrm{~g} / \mathrm{dl}$. Lebih dari separuh contoh (61.7\%) tidak mengalami anemia, 32.3 persen yang mengalami anemia ringan dan 6.0 persen mengalami anemia sedang (Tabel 1).

Tabel 1. Sebaran Contoh berdasarkan Status Anemia

\begin{tabular}{cccc}
\hline $\begin{array}{c}\text { Status } \\
\text { Anemia }\end{array}$ & $\begin{array}{c}\text { Hemoglobin } \\
(\mathrm{g} / \mathrm{dl})\end{array}$ & $\mathrm{n}$ & $\%$ \\
\hline Normal & $\geq 12.0$ & 247 & 61.7 \\
Ringan & $10.0-11.9$ & 129 & 32.3 \\
Sedang & $7.0-9.9$ & 24 & 6.0 \\
Berat & $<7.0$ & 0 & 0 \\
\hline & Total & 400 & 100 \\
\hline
\end{tabular}

Hasil studi di berbagai wilayah di Indonesia menunjukkan prevalensi anemia pada remaja wanita cukup beragam. Prevalensi anemia di SMU Jakarta Timur 17.2 \% (AngelesAgdeppa et al., 1997), di SMP dan SMU Jawa Tengah 57.4\% dan Jawa Timur 80.2\% (Depkes, 2003), di SMU Tangerang 54\% dan SMU Jakarta Timur 45\% (Dillon, 2005), di Sekolah Madrasah Madura 48.1\% (Sari et al., 2004), di SMP Jawa Timur 26\% (Soekarjo et al., 2004), di SD Tangerang 26.7\% (Kurniawan \& Muslimatun, 2005), dan mahasiswi 25.1\% (Briawan et al., 2008). Secara nasional prevalensi anemia remaja wanita umur 10-19 tahun sebesar 30\% (Permaesih dan Herman, 2005). Berdasarkan klasifikasi WHO (2001), anemia menjadi masalah kesehatan masyarakat tingkat sedang jika prevalensinya 20-39\%.

Pada studi ini terdapat contoh yang termasuk kategori anemia sedang, yang diduga akan berdampak pada status imunitas dan fungsi kognitifnya (Ruel, 2001). Menurut Soekirman (2000), anemia pada remaja dapat menurunkan daya tahan tubuh dan kemampuan kerja fisik serta prestasi belajar.

\section{Usia dan Status Gizi Antropometri}

Usia

WHO mendefinisikan usia remaja antara usia 10-19 tahun. Rata-rata usia contoh adalah $13.7 \pm 1.9$ tahun dengan kisaran antara 10-18 tahun. Untuk melihat prevalensi anemia, usia dikategorikan berdasarkan kelompok umur kebutuhan gizi (10-12 tahun, 13-15 tahun dan 1618 tahun).
Tabel 2. Sebaran Contoh berdasarkan Kelompok Usia dan Status Anemia

\begin{tabular}{lrrrrrr}
\hline \multirow{2}{*}{ Usia } & \multicolumn{2}{c}{ Anemia } & \multicolumn{2}{c}{$\begin{array}{c}\text { Tidak } \\
\text { Anemia }\end{array}$} & \multicolumn{2}{c}{ Total } \\
\cline { 2 - 8 } & $\mathbf{n}$ & \multicolumn{1}{c}{$\%$} & \multicolumn{1}{c}{$\mathbf{n}$} & $\%$ & $\mathbf{n}$ & $\%$ \\
\hline $10-12$ tahun & 43 & 28.1 & 115 & 46.6 & 158 & 39.5 \\
$13-15$ tahun & 77 & 50.3 & 79 & 31.9 & 156 & 39.0 \\
$16-18$ tahun & 33 & 21.6 & 53 & 21.5 & 86 & 21.5 \\
\hline Total & 153 & 100 & 247 & 100 & 400 & 100 \\
\hline
\end{tabular}

Pada kelompok usia 10-12 tahun prevalensi anemia sebesar $28.1 \%$. Prevalensi tersebut lebih sedikit diduga karena kebanyakan siswi belum mengalami menstruasi. Pada penelitian ini, hampir separuh siswi SMP yang berusia antara 10-12 tahun belum mengalami menstruasi. Siswi SMP sebanyak $48.5 \%$ belum mengalami menstruasi, sedangkan siswi SMK hampir seluruhnya $(99.5 \%)$ sudah mengalami menstruasi (Briawan et al., 2009).

Lebih dari separuh contoh $(50.3 \%)$ menderita anemia berada pada kisaran usia 13-15 tahun. Hal tersebut menunjukkan kecenderungan siswi usia tersebut mengalami risiko anemia lebih tinggi dibandingkan kelompok usia lainnya. Pada kisaran usia 13-15 tahun, seorang remaja baru mengalami menstruasi sehingga kecenderungan anemia lebih besar akibat kehilangan darah. Studi pada mahasiswi di Bogor menunjukkan rata-rata umur menarche adalah 13.0 tahun (Briawan, 2008). Studi Dillon (2005) di Tangerang dan Jakarta Pusat bahkan menunjukkan rata-rata menstruasi satu tahun lebih awal, yaitu berturut-turut 12.2 tahun dan 12.3 tahun.

Persentase anemia terkecil terdapat pada kisaran usia 16-18 tahun. Hal ini sesuai dengan hasil penelitian Maharani (2001) yang menunjukkan bahwa usia diatas 18 tahun cenderung lebih kecil untuk menderita anemia daripada usia di bawahnya. Menurut FAO/WHO (2001), kebutuhan zat besi wanita usia 16-18 tahun lebih rendah dibandingkan dengan usia remaja sebelumnya.

Analisis korelasi menunjukkan terdapat hubungan yang signifikan antara usia dengan status anemia $(r=0.131, p=0.009)$. Hal ini memperlihatkan bahwa semakin tinggi usia maka semakin besar kecenderungan seseorang mengalami anemia. Hasil penelitian Hulu (2004) pada siswi SMK menunjukkan kecenderungan anemia pada siswi yang lebih tua. Ini diduga berkaitan dengan terjadinya menstruasi pada siswi yang berusia lebih tua. Pada penelitian ini, hampir separuh siswi SMP yang berusia antara 10-12 tahun belum mengalami 
menstruasi. Dillon (2005) menyatakan bahwa remaja terutama yang telah mengalami menstruasi lebih rentan terhadap anemia dibandingkan yang belum menstruasi.

\section{Status Gizi Antropometri}

Rata-rata IMT adalah $19.3 \pm 3.3 \mathrm{~kg} / \mathrm{m}^{2}$ dengan kisaran $11.9 \mathrm{~kg} / \mathrm{m}^{2}$ sampai $37.5 \mathrm{~kg} / \mathrm{m}^{2}$. Sebagian besar contoh berada pada kategori kurus $(48.0 \%) \quad(I M T<18.5)$. Proporsi siswi anemia relatif tidak jauh berbeda antara yang kurus dan normal. Proporsi contoh tidak anemia dengan kategori kurus sebesar $47.4 \%$, sedangkan proporsi contoh anemia pada kategori normal $49.7 \%$. Analisis korelasi Spearman menunjukkan bahwa tidak terdapat hubungan yang signifikan antara IMT dengan status anemia $(p>0.1)$.

Tabel 3. Sebaran Contoh berdasarkan Status Gizi dan Status Anemia

\begin{tabular}{ccccccc}
\hline \multirow{2}{*}{$\begin{array}{c}\text { Status } \\
\text { Gizi }\end{array}$} & \multicolumn{2}{c}{ Anemia } & \multicolumn{2}{c}{\begin{tabular}{c} 
Tidak \\
\multicolumn{2}{c}{ Anemia }
\end{tabular}} & \multicolumn{2}{c}{ Total } \\
\cline { 2 - 7 } & $\mathrm{n}$ & $\%$ & $\mathrm{n}$ & $\%$ & $\mathrm{n}$ & $\%$ \\
\hline Kurus & 75 & 49.1 & 117 & $\mathbf{4 7 . 4}$ & 192 & $\mathbf{4 8 . 0}$ \\
Normal & 76 & 49.7 & 113 & 45.7 & 189 & 47.3 \\
Gemuk & 1 & 0.6 & 9 & 3.6 & 10 & 2.5 \\
Obese & 1 & 0.6 & 8 & 3.3 & 9 & 2.2 \\
\hline Total & 153 & 100 & 247 & 100 & 400 & 100 \\
\hline
\end{tabular}

Hasil sebaliknya ditunjukkan pada penelitian Permaesih dan Herman (2005) bahwa remaja yang mempunyai IMT kurang atau tubuh kurus mempunyai risiko 1.5 kali untuk menderita anemia. Thompson (2007) menyatakan bahwa IMT mempunyai korelasi positif dengan konsentrasi hemoglobin, artinya seseorang yang memiliki IMT kurang maka akan berisiko menderita anemia. Diduga peubah status menstruasi, yaitu ketika sebagian besar contoh belum menstruasi akan berpengaruh terhadap hasil analisis korelasi tersebut.

\section{Menstruasi}

Menstruasi ialah perdarahan secara periodik dan siklik dari uterus disertai pelepasan endometrium. Kebutuhan zat besi akan meningkat pada remaja putri sehubungan dengan terjadinya menstruasi (Hallberg, 2001).

\section{Status Menstruasi}

Status menstruasi adalah keadaan seorang wanita sudah atau belum mengalami menstruasi. Sebagian besar contoh (75.5\%) sudah mengalami menstruasi dan sisanya (24.5\%) belum mengalami menstruasi. Pada penelitian ini, proporsi terbesar contoh berusia antara
10-12 tahun dan hampir separuh contoh tidak anemia berada pada kisaran usia tersebut.

Tabel 4. Sebaran Contoh berdasarkan Status Menstruasi dan Status Anemia

\begin{tabular}{lcccccc}
\hline \multirow{2}{c}{$\begin{array}{c}\text { Status } \\
\text { Menstruasi }\end{array}$} & \multicolumn{2}{c}{ Anemia } & \multicolumn{2}{c}{$\begin{array}{c}\text { Tidak } \\
\text { Anemia }\end{array}$} & \multicolumn{2}{c}{ Total } \\
\cline { 2 - 7 } & $\mathbf{n}$ & $\%$ & $\mathbf{n}$ & $\%$ & $\mathbf{n}$ & $\%$ \\
\hline Sudah & 125 & $\mathbf{8 1 . 7}$ & 177 & $\mathbf{7 1 . 7}$ & 302 & $\mathbf{7 5 . 5}$ \\
Belum & 28 & 18.3 & 70 & 28.3 & 98 & 24.5 \\
\hline Total & 153 & 100 & 247 & 100 & 400 & 100 \\
\hline
\end{tabular}

Tabel 4 menunjukkan bahwa contoh yang sudah mengalami menstruasi lebih banyak mengalami anemia (81.7\%) dibandingkan dengan yang belum menstruasi (18.3\%). Hal ini memperlihatkan kecenderungan terjadinya anemia pada seseorang yang sudah mengalami menstruasi. Hasil analisis korelasi menunjukkan terdapat hubungan signifikan antara status menstruasi dengan status anemia $(r=0.113, p$ $=0.023$ ).

Seseorang yang telah menstruasi memiliki kecenderungan untuk mengalami anemia dibandingkan yang belum menstruasi. Penelitian Dillon (2005) menunjukkan remaja yang telah mengalami menstruasi, dibandingkan dengan yang belum menstruasi, lebih rentan terhadap anemia. Wanita umumnya mempunyai simpanan zat besi yang lebih rendah dibandingkan pria dan hal inilah yang membuat wanita lebih rentan mengalami anemia saat asupan zat besi kurang atau kebutuhan meningkat seperti saat menstruasi (Hallberg, 2001).

\section{Frekuensi Menstruasi}

Frekuensi menstruasi dibedakan menjadi rendah (2-3 bulan sekali), normal (sebulan sekali), dan tinggi (sebulan 2 kali). Sebagian besar contoh memiliki frekuensi menstruasi normal $(92.0 \%)$, baik pada kelompok yang anemia (88.8\%) maupun tidak anemia (94.4\%). Terdapat sekitar 3.0 persen contoh memiliki frekuensi menstruasi tinggi. Frekuensi menstruasi yang tinggi lebih sering dialami contoh anemia (4.8\%). Hasil uji korelasi menunjukkan tidak terdapat hubungan signifikan antara frekuensi menstruasi dengan status anemia $(p>0.1)$.

Saat menstruasi terjadi pengeluaran darah dari dalam tubuh. Semakin sering menstruasi berlangsung, maka semakin banyak pengeluaran dari tubuh. Hal tersebut mengakibatkan pengeluaran besi meningkat. Adanya frekuensi menstruasi tidak normal dipengaruhi oleh beberapa faktor diantaranya yaitu stres, perubahan berat badan, olah raga yang berlebihan, dan keluhan menstruasi (Affandi, 1990). 
Tabel 5. Sebaran Contoh berdasarkan Frekuensi Menstruasi dan Status Anemia

\begin{tabular}{lcccccc}
\hline \multirow{2}{*}{$\begin{array}{c}\text { Frekuensi } \\
\text { Menstruasi }\end{array}$} & \multicolumn{2}{c}{ Anemia } & \multicolumn{2}{c}{$\begin{array}{c}\text { Tidak } \\
\text { Anemia }\end{array}$} & \multicolumn{2}{c}{ Total } \\
\cline { 2 - 7 } & $\mathbf{n}$ & $\%$ & $\mathrm{n}$ & $\%$ & $\mathrm{n}$ & $\%$ \\
\hline Rendah & 8 & 6.4 & 7 & 3.9 & 15 & 5.0 \\
Normal & 111 & $\mathbf{8 8 . 8}$ & 167 & $\mathbf{9 4 . 4}$ & 278 & $\mathbf{9 2 . 0}$ \\
Tinggi & 6 & 4.8 & 3 & 1.7 & 9 & 3.0 \\
\hline Total & 125 & 100 & 177 & 100 & 302 & 100 \\
\hline
\end{tabular}

\section{Banyaknya Darah Menstruasi}

Banyaknya darah menstruasi diindikasikan dengan banyaknya pembalut yang digunakan setiap hari. Jumlah darah yang hilang selama satu periode menstruasi berkisar 20-25 cc dan dianggap abnormal jika kehilangan darah menstruasi lebih dari $80 \mathrm{ml}$ (Krummel dan Krish-Etherton, 1996). Tabel 5 menunjukkan kurang lebih separuh contoh (50.3\%) mengganti pembalut 3-4 kali setiap hari. Lebih dari separuh contoh anemia (55.2\%) mengganti pembalut 3-4 kali setiap hari, sedangkan hampir separuh contoh tidak anemia (49.1\%) mengganti pembalut 1-2 kali setiap harinya. Hal ini menunjukkan bahwa contoh anemia cenderung mengalami kehilangan darah yang lebih tinggi dilihat dari jumlah pembalut yang diganti setiap hari. Meskipun demikian uji korelasi menunjukkan tidak terdapat hubungan yang signifikan ( $p>0.1)$.

Tabel 6. Sebaran Contoh berdasarkan Banyaknya Menstruasi

\begin{tabular}{lcccccc}
\hline \multirow{2}{*}{$\begin{array}{c}\text { Pemakaian } \\
\text { pembalut }\end{array}$} & \multicolumn{2}{c}{ Anemia } & \multicolumn{2}{c}{$\begin{array}{c}\text { Tidak } \\
\text { Anemia }\end{array}$} & \multicolumn{2}{c}{ Total } \\
\cline { 2 - 7 } & $\mathrm{n}$ & $\%$ & $\mathrm{n}$ & $\%$ & $\mathrm{n}$ & $\%$ \\
\hline $\begin{array}{l}\text { Ganti 1-2 } \\
\text { kali/hari }\end{array}$ & 54 & 43.2 & 87 & 49.1 & 141 & 46.7 \\
$\begin{array}{l}\text { Ganti 3-4 } \\
\text { kali/hari }\end{array}$ & 69 & 55.2 & 83 & 46.9 & 152 & 50.3 \\
$\begin{array}{l}\text { Ganti 5-6 } \\
\text { kali/hari }\end{array}$ & 2 & 1.6 & 6 & 3.4 & 8 & 2.7 \\
$\begin{array}{l}\text { Ganti }>6 \\
\text { kali/hari }\end{array}$ & 0 & 0 & 1 & 0.6 & 1 & 0.3 \\
\hline Total & 125 & 100 & 177 & 100 & 302 & 100 \\
\hline
\end{tabular}

Affandi (1990) menyatakan apabila darah yang keluar saat menstruasi cukup banyak, jumlah zat besi yang hilang dari tubuh juga cukup besar. Banyaknya darah yang keluar berbeda-beda pada setiap orang dan bahkan dapat berbeda setiap bulannya. Tidak adanya hubungan antara banyaknya menstruasi dengan status anemia diduga karena pengukuran banyaknya menstruasi dengan pendekatan pemakaian pembalut bersifat subyektif, dan mungkin tidak menggambarkan jumlah darah yang keluar.

\section{Lama Menstruasi}

Lama menstruasi biasanya antara 3-5 hari dan dianggap tidak normal jika lebih dari 8 atau 9 hari. Lama menstruasi dikatakan rendah jika kurang dari tiga hari, normal apabila berada diantara 3-7 hari, dan tinggi jika lebih dari delapan hari. Tabel 7 menunjukkan bahwa sebagian besar contoh (87.7\%) memiliki lama menstruasi yang tergolong normal (3-7 hari). Sebagian besar contoh anemia $(86.4 \%)$ dan tidak anemia (88.7\%) memiliki lama menstruasi dengan kategori normal.

Tabel 7. Sebaran Contoh berdasarkan Lama Menstruasi dan Status Anemia

\begin{tabular}{lcccccc}
\hline \multirow{2}{*}{$\begin{array}{c}\text { Lama } \\
\text { menstruasi }\end{array}$} & \multicolumn{2}{c}{ Anemia } & \multicolumn{2}{c}{$\begin{array}{c}\text { Tidak } \\
\text { Anemia }\end{array}$} & \multicolumn{2}{c}{ Total } \\
\cline { 2 - 7 } & $\mathrm{n}$ & $\%$ & $\mathrm{n}$ & $\%$ & $\mathrm{n}$ & $\%$ \\
\hline Rendah & 1 & 0.8 & 1 & 0.6 & 2 & 0.7 \\
Normal & 108 & $\mathbf{8 6 . 4}$ & 157 & $\mathbf{8 8 . 7}$ & 265 & $\mathbf{8 7 . 7}$ \\
Tinggi & 16 & 12.8 & 19 & 10.7 & 35 & 11.6 \\
\hline Total & 125 & 100 & 177 & 100 & 302 & 100 \\
\hline
\end{tabular}

Pada usia remaja, kehilangan darah menstruasi tidak berbeda dengan kelompok usia reproduktif lainnya (Hallberg, 2001). Rata-rata kehilangan darah selama menstruasi 84 $\mathrm{ml}$, sehingga setiap hari membutuhkan tambahan zat besi $0.56 \mathrm{mg}$. Tidak terdapat perbedaan kehilangan jumlah darah menstruasi antar waktu (bulan), namun terdapat variasi antar individu. Rata-rata kehilangan zat besi pada siklus menstruasi 28 hari sebesar 0.56 $\mathrm{mg} /$ hari.

Hasil analisis korelasi menunjukkan tidak terdapat hubungan yang signifikan antara lama menstruasi dengan status anemia $(p>0.1)$. Perbedaan lama menstruasi seseorang dipengaruhi oleh banyak faktor antara lain lingkungan, keturunan, usia, dan ovulasi (Affandi, 1990).

\section{Riwayat Penyakit}

Anemia dapat menurunkan daya tahan tubuh sehingga mudah terkena infeksi (Permaesih dan Herman, 2005). Infeksi merupakan faktor yang penting dalam menimbulkan kejadian anemia, dan anemia merupakan konsekuensi dari peradangan dan asupan makanan yang tidak memenuhi kebutuhan zat besi. Sebagian besar contoh baik yang anemia maupun tidak anemia (99.3\%) tidak memiliki riwayat penyakit yang berhubungan dengan anemia seperti malaria, tuberculosis, dan kecacingan. Hanya terdapat sekitar 0.8 persen contoh yang memiliki riwayat penyakit yang berhubungan dengan anemia (malaria dan kecacingan). 
Hasil uji korelasi menunjukkan tidak terdapat hubungan signifikan antara riwayat penyakit dengan status anemia $(p>0.1)$. Secara statistik hubungan yang tidak signifikan tersebut diduga karena kecilnya proporsi contoh yang menderita penyakit. Selain itu diduga pengukuran peubah riwayat penyakit dilakukan secara retrospektif dengan wawancara yang validitasnya terbatas.

Penyakit infeksi terutama malaria, cacing, dan infeksi lainnya seperti tuberculosis merupakan faktor penting yang memberikan kontribusi terhadap kejadian anemia. Menurut Dreyfuss et al. (2000), adanya infeksi cacing tambang menyebabkan kehilangan darah tersebut mengakibatkan defisiensi besi. Infeksi pada penderita malaria dapat menyebabkan anemia dengan cara merusak sel darah merah (hemolisis) dan menekan produksi sel darah merah yang baru (MOST, 2004).

\section{Perilaku Hidup Bersih dan Sehat}

Perilaku hidup sehat sangat erat kaitannya dengan higiene perorangan (personal hygiene). Yang termasuk dalam higiene perorangan adalah mencuci tangan dengan air bersih. Sebagian besar contoh memiliki kebiasaan mencuci tangan baik dengan atau tanpa sabun sebelum makan, baik untuk yang anemia (90.8\%) maupun tidak anemia (91.5\%).

Mencuci tangan sebelum makan merupakan salah satu faktor determinan status anemia. Penelitian yang dilakukan pada siswa SD menunjukkan bahwa seseorang yang rutin mencuci tangan ternyata mempunyai risiko yang lebih kecil untuk terkena anemia. Melalui membiasakan mencuci tangan sebelum makan diharapkan kuman-kuman tidak ikut masuk ke dalam mulut, yang selanjutnya akan menyebabkan kecacingan sebab cacing di perut sebagai pemicu terjadinya anemia (Irawati et al., 2000).

Analisis korelasi menunjukkan tidak terdapat hubungan signifikan antara perilaku hidup bersih dan sehat dengan status anemia ( $p$ $>0.1$ ). Secara statistik proporsi contoh yang tidak memiliki kebiasaan mencuci tangan sangat kecil.

\section{Aktivitas Fisik}

Aktivitas remaja didefinisikan sebagai kegiatan fisik yang biasa dilakukan oleh remaja dalam kehidupan sehari-hari. Lebih dari separuh contoh memiliki aktivitas fisik olahraga ringan (jalan santai, lempar cakram, senam pernapasan), yaitu $50.3 \%$ anemia dan $53.0 \%$ tidak anemia. Hanya terdapat satu persen contoh yang melakukan olahraga berat (lari cepat $>10$ $\mathrm{km}$, senam aerobik).

Tabel 8. Sebaran Contoh berdasarkan Aktivitas Fisik dan Status Anemia

\begin{tabular}{lcccccc}
\hline \multirow{2}{*}{$\begin{array}{c}\text { Akifitas } \\
\text { Fisik }\end{array}$} & \multicolumn{2}{c}{ Anemia } & \multicolumn{2}{c}{$\begin{array}{c}\text { Tidak } \\
\text { Anemia }\end{array}$} & \multicolumn{2}{c}{ Total } \\
\cline { 2 - 7 } & $\mathrm{n}$ & $\%$ & $\mathrm{n}$ & $\%$ & $\mathrm{n}$ & $\%$ \\
\hline $\begin{array}{l}\text { Olahraga } \\
\text { ringan }\end{array}$ & 77 & $\mathbf{5 0 . 3}$ & 131 & $\mathbf{5 3 . 0}$ & 208 & $\mathbf{5 2 . 0}$ \\
$\begin{array}{l}\text { Olahraga } \\
\text { sedang }\end{array}$ & 75 & 49.0 & 113 & 45.8 & 188 & 47.0 \\
$\begin{array}{l}\text { Olahraga } \\
\text { berat }\end{array}$ & 1 & 0.7 & 3 & 1.2 & 4 & 1.0 \\
\hline Total & 153 & 100 & 247 & 100 & 400 & 100 \\
\hline
\end{tabular}

Sebanyak 49.0\% contoh anemia yang melakukan aktivitas olahraga sedang seperti basket, bola voli, lari, dan senam aerobik; lebih tinggi dibandingkan dengan contoh yang tidak anemia (45.8\%). Olah raga yang sangat intensif merupakan salah satu penyebab anemia (Krummel \& Kris-Etherton, 1996). Olahraga berat dapat meningkatkan kebutuhan zat besi hingga 1-2 mg perhari. Hal ini dapat disebabkan oleh kombinasi beberapa faktor seperti kehilangan zat besi melalui keringat, kehilangan darah dari sistem gastrointestinal, dan hemolisis (Zhu \& Haas, 1997). Menurut Akabas (Hallberg, 2001), pengeluaran zat besi dapat melalui keringat, feses dan urine, atau hemolisis intravaskular. Hasil studi pada atlet wanita menunjukkan kehilangan zat besi terjadi melalui keringat dan konsentrasi zat besi terbesar dalam keringat terjadi selama 30 menit pertama olahraga.

Hasil uji korelasi menunjukkan tidak terdapat hubungan signifikan antara aktivitas fisik dengan status anemia contoh $(p>0.1)$. Hal tersebut diduga karena intensitas aktivitas fisik yang dilakukan tidak intensif seperti yang secara teori yang dapat menyebabkan anemia, misalnya pada atlet remaja.

\section{Frekuensi Konsumsi Pangan}

Masalah utama pemanfaatan zat besi oleh tubuh adalah rendahnya penyeraban di dalam usus. Penyeraban zat besi dipengaruhi oleh dua faktor, yaitu absorbsi besi heme dan non-heme yang menunjukkan keberadaan dua jenis zat besi yang berbeda di dalam pangan. Sumber heme pada pangan manusia adalah daging, ikan, dan unggas, sedangkan sumber non-heme adalah sereal, kacang-kacangan, sayur dan buah (FAO/WHO, 2001). Pencatatan frekuensi pangan sumber zat besi dibagi menjadi lauk hewani, lauk nabati, sayuran, buah- 
buahan, makanan jajanan, minuman, dan sup lemen. Ketujuh jenis pangan ini kemudian dikategorikan menurut frekuensi konsumsi selama seminggu yaitu tidak pernah, jarang $(<3$ kali), kadang-kadang (3-6 kali), dan setiap hari.

\section{Frekuensi Konsumsi Lauk Hewani}

Besi heme yang terdapat dalam pangan hewani dapat diserab dua kali lipat daripada besi nonheme. Oleh karena itu kurangnya konsumsi pangan sumber heme dapat mempengaruhi penyeraban zat besi.

Dari sembilan lauk hewani atau sumber heme, enam pangan diantaranya tidak pernah dikonsumsi lebih dari separuh contoh yang anemia maupun tidak anemia seperti ikan asin, daging sapi, hati sapi, hati ayam, telur bebek, dan telur puyuh.

Hampir separuh contoh jarang mengonsumsi ikan segar (47.3\%) dan daging ayam (48.5\%). Jika dilihat dari frekuensinya, persentase contoh anemia yang jarang mengonsumsi ikan segar dan daging ayam sedikit lebih tinggi dibandingkan dengan yang tidak anemia.

Sumber zat besi dari pangan hewani seperti daging, unggas, dan ikan mempunyai ketersediaan biologis (bioavalibilitas) yang tinggi. Pangan hewani seperti daging sapi, daging unggas, dan ikan memiliki Meat, Fish, Poultry Factor (MFP Factor) yang dapat meningkatkan penyeraban besi. Hasil pencernaan ketiga pangan tersebut menghasilkan asam amino cysteine dalam jumlah besar, yang kemudian dapat mengikat besi dan membantu penyerabannya (FAO/WHO, 2001).

Konsumsi telur ayam contoh dengan frekuensi kadang-kadang (42.5\%) dan merupakan lauk hewani dengan persentase terbesar yang dikonsumsi oleh contoh setiap hari (10.3\%). Analisis menunjukkan korelasi negatif yang signifikan antara frekuensi konsumsi telur ayam dan telur bebek dengan status anemia ( $p<$ $0.1)$. Hal ini diduga karena saat konsumsi telur bersamaan dengan bahan pangan lain yang dapat menghambat penyeraban besi. Senyawa penghambat tersebut adalah fitat, inositol, fosfat, dan polifenol. Senyawa penghambat ter sebut terdapat pada produk sereal, kacangkacangan, kopi, teh, sayuran, bumbu-bumbuan, termasuk susu kedelai (FAO/WHO, 2001).

\section{Frekuensi Konsumsi Lauk Nabati}

Besi dalam makanan terdapat dalam bentuk besi heme (dalam makanan hewani) dan besi nonheme (dalam makanan nabati). Lauk nabati dalam penelitian ini meliputi tempe, tahu, dan kacang-kacangan (kacang tanah dan kacang hijau).

Frekuensi lauk nabati contoh berkisar antara 0-6 kali seminggu. Tempe dikonsumsi dalam frekuensi kadang-kadang (36.8\%) baik oleh contoh anemia maupun tidak anemia, sedangkan tahu dikonsumsi dalam frekuensi jarang (30.0\%). Lebih dari separuh contoh (59.7\%) tidak pernah mengkonsumsi lauk nabati seperti kacang-kacangan. Lauk nabati dikonsumsi kurang dari 20 persen contoh dengan frekuensi setiap hari.

Asam fitat yang terkandung dalam kedelai dan hasil olahannya dapat menghambat penyeraban besi. Namun karena zat besi yang terkandung dalam kedelai dan hasil olahannya cukup tinggi, hasil akhir terhadap penyeraban besipun biasanya akan positif (Almatsier 2001). Walaupun demikian, hasil korelasi Spearman menunjukkan tidak terdapat hubungan signifikan antara frekuensi konsumsi pangan nabati dengan status anemia $(p>0.1)$.

\section{Frekuensi Konsumsi Sayuran}

Sayuran merupakan pangan sumber vitamin dan mineral, termasuk zat besi. Namun sayuran juga mengandung asam oksalat dan serat yang dapat menghambat penyeraban zat besi di dalam tubuh. Jenis sayuran dalam penelitian ini meliputi waluh, kembang kol, kol, wortel, kentang, sawi, dan sayuran hijau (brokoli, daun singkong, bayam, kangkung, daun pepaya).

Dari 11 jenis sayuran, 7 diantaranya tidak pernah dikonsumsi contoh baik pada contoh yang anemia maupun tidak anemia diantaranya waluh, kembang kol, kol, brokoli, daun singkong, sawi, dan daun pepaya. Hampir separuh contoh baik anemia maupun tidak anemia jarang mengkonsumsi wortel $(47.5 \%)$ dan kentang (43.0\%).

Kurang dari 5 persen contoh mengonsumsi sayuran setiap hari. Contoh anemia lebih sering mengkonsumsi sayuran dibandingkan contoh tidak anemia dilihat dari frekuensi konsumsi setiap hari. Hal ini berbeda dengan hasil penelitian Hulu (2004) yang menunjukkan bahwa contoh yang tidak anemia lebih sering mengkonsumsi sayuran dibandingkan contoh anemia.

Sayuran hijau seperti bayam lebih jarang dikonsumsi oleh contoh anemia. Sayuran daun berwarna hijau memiliki kandungan zat besi 
yang tinggi sehingga jika sering dikonsumsi maka akan meningkatkan cadangan zat besi di dalam tubuh. Beberapa jenis sayuran hijau juga mengandung asam oksalat, namun efektifitas hambatan absorbsinya relatif lebih kecil dibandingkan asam fitat (serealia) dan tanin (teh dan kopi) (FAO/WHO 2001).

Korelasi Spearman menunjukkan terdapat hubungan signifikan antara frekuensi konsumsi sayuran waluh dan sawi dengan status anemia dengan nilai korelasi negatif $(p<0.1)$. $\mathrm{Hal}$ ini memperlihatkan semakin jarang waluh dan sawi dikonsumsi maka kecenderungan menderita anemia akan semakin kecil. Hal ini diduga karena waluh dan sawi menghambat penyeraban besi akibat asam oksalat yang terkandung didalamnya. Asam oksalat akan mengikat besi sehingga apabila dikonsumsi dalam jumlah banyak akan mempersulit penyeraban besi oleh tubuh.

\section{Frekuensi Konsumsi Buah-buahan}

Buah-buahan merupakan pangan sumber vitamin dan mineral. Vitamin yang banyak terkandung dalam buah-buahan diantaranya adalah vitamin C. Vitamin C sangat membantu penyeraban zat besi terutama zat besi nonheme.

Dari 7 jenis buah-buahan, 6 diantaranya tidak pernah dikonsumsi lebih dari separuh contoh baik pada contoh yang anemia maupun tidak anemia yaitu pepaya, tomat, jambu biji, mangga, nenas, dan pisang. Hampir separuh dari contoh (42.7\%) mengkonsumsi jeruk dalam frekuensi jarang (< 3 kali seminggu) dan kurang dari 12 persen contoh mengonsumsi buahbuahan setiap hari.

Buah-buahan sumber vitamin C seperti jeruk, pepaya, tomat, jambu biji, dan mangga dapat membantu penyeraban zat besi. Asam organik seperti vitamin C dapat membantu penyeraban zat besi nonheme dengan cara mengubah bentuk feri menjadi bentuk fero yang lebih mudah diserab. Contoh anemia lebih sering mengkonsumsi buah-buahan dibandingkan contoh tidak anemia.

Korelasi Spearman menunjukkan terdapat hubungan signifikan antara frekuensi konsumsi buah-buahan dengan status anemia ( $p<$ 0.1 ) yaitu pada konsumsi pepaya. Hal ini memperlihatkan semakin jarang pepaya dikonsumsi maka kecenderungan menderita anemia akan semakin kecil. Hal ini diduga karena walaupun pepaya kaya akan vitamin C yang dapat membantu penyeraban zat besi, namun apabila pepaya dikonsumsi bersamaan dengan bahan pangan lain yang dapat menghambat penyeraban besi seperti asam oksalat yang terkandung dalam sayuran hijau atau tanin maka pengaruh akhirnya dapat negatif.

\section{Frekuensi Konsumsi Makanan Jajanan}

Lebih dari separuh contoh tidak pernah mengonsumsi makanan jajanan seperti bakso, mie, dan gorengan. Hanya sekitar 5 persen contoh yang mengkonsumsi makanan jajanan setiap hari. Persentase contoh yang anemia sedikit lebih rendah dibandingkan contoh yang tidak anemia jika dilihat dari frekuensi konsumsi makanan jajanan setiap hari. Hal ini menunjukkan bahwa contoh yang anemia jarang mengkonsumsi makanan jajanan.

Makanan jajanan juga memberikan kontribusi pada cadangan zat besi tubuh karena terdapat zat besi yang terkandung didalamnya walaupun sedikit. Hasil analisis korelasi Spearman menunjukkan bahwa tidak terdapat hubungan yang signifikan antara frekuensi jajanan dengan status anemia contoh $(p>0.1)$. Hal ini diduga karena jarangnya contoh mengonsumsi makanan jajanan di sekolah.

\section{Frekuensi Konsumsi Minuman dan Suplemen}

Minuman dalam penelitian ini meliputi teh, kopi, dan susu serta konsumsi suplemen. Teh lebih sering dikonsumsi contoh anemia dilihat dari frekuensi konsumsi teh setiap hari. Hampir sebagian besar contoh baik contoh anemia maupun tidak anemia tidak pernah mengkonsumsi kopi. Terdapat sekitar 1.3 persen contoh anemia yang mengkonsumsi kopi setiap hari.

Remaja menyukai minuman ringan, teh, dan kopi yang frekuensinya lebih sering dibandingkan konsumsi susu. Teh dan kopi mengandung tanin yang dapat menghambat absorpsi besi dengan mengikatnya (FAO/WHO, 2001).

Susu merupakan pangan sumber protein yang baik yang memiliki bioavailabilitas tinggi. Protein yang terkandung di dalamnya berperan dalam distribusi zat gizi termasuk distribusi zat besi. Namun susu juga mengandung kalsium yang tinggi yang dapat menghambat penyeraban zat besi. Hampir separuh contoh (44.8\%) tidak pernah mengkonsumsi susu. Hanya sekitar 18.5 persen contoh yang mengonsumsi susu setiap hari dan persentase terbesar konsumsi susu terdapat pada contoh yang tidak anemia (19.8\%). Terdapat 20.3 persen contoh anemia yang jarang mengonsumsi susu. Hal ini memperlihatkan kecenderungan frekuensi konsumsi susu contoh tidak anemia relatif lebih sering dibandingkan contoh anemia. 
Produk suplemen meliputi suplemen vitamin C, minyak ikan, dan suplemen penambah darah. Sebagian besar contoh (75.5\%) tidak pernah mengkonsumsi suplemen. Terdapat 7.7 persen contoh yang mengkonsumsi suplemen setiap hari dan persentase terbesar konsumsi suplemen terdapat pada contoh yang anemia (8.5\%). Ini memperlihatkan bahwa contoh anemia lebih sering mengonsumsi suplemen dibandingkan contoh tidak anemia diduga terkait dengan anemia yang dialaminya. Secara keseluruhan hasil korelasi Spearman menunjukkan tidak terdapat hubungan yang signifikan antara frekuensi konsumsi minuman dan suplemen dengan status anemia ( $p>0.1)$.

\section{Analisis Faktor Risiko Anemia}

Uji regresi logistik dilakukan untuk mengetahui faktor risiko yang signifikan terhadap status anemia. Faktor risiko yang signifikan terhadap status anemia remaja putri adalah usia (tahun) dan status gizi antropometri (kurus dan normal).

Tabel 9. Uji Regresi Logistik Faktor Risiko Anemia

\begin{tabular}{|c|c|c|c|c|}
\hline Variabel & Faktor Risiko & OR & Sig. & $\mathrm{Cl}: 90 \%$ \\
\hline Usia & $\begin{array}{l}13-15 \text { tahun } \\
(13-15 \text { thn }=1 \\
10-12 \text { thn }=0)\end{array}$ & 2.73 & $0.001^{*}$ & $\begin{array}{l}1.67- \\
4.54\end{array}$ \\
\hline \multirow[t]{2}{*}{ Status Gizi } & $\begin{array}{l}\text { Kurus } \\
(\text { IMT }<18.5=1, \\
\text { IMT }>25=0)\end{array}$ & 8.32 & $0.006^{*}$ & $\begin{array}{l}2.27- \\
29.15\end{array}$ \\
\hline & $\begin{array}{l}\text { Normal } \\
(18.5<I M T<25=1 \text {, } \\
\text { IMT }>25=0)\end{array}$ & 6.73 & 0.013 & $\begin{array}{l}1.79- \\
22.53\end{array}$ \\
\hline Konstanta & & 0.05 & 0.000 & \\
\hline
\end{tabular}

* Signifikan pada taraf kepercayaan 0.1

Remaja putri pada kisaran usia 13-15 tahun memiliki kecenderungan untuk mengalami anemia 2.73 kali lebih besar dibandingkan remaja putri yang berusia 10-12 tahun (OR=2.73; Cl 90\%: 1.67-4.54). Hal ini karena remaja usia 13-15 tahun kebanyakan sudah mengalami menstruasi, sehingga kecenderungan anemia lebih besar dibandingkan usia di bawahnya (kurang lebih $50 \%$ belum menstruasi).

Hasil penelitian Dillon (2005) terhadap remaja putri di Tangerang menunjukkan bahwa rata-rata usia menarche adalah 12 tahun. Remaja terutama yang telah mengalami menstruasi, dibandingkan dengan yang belum menstruasi, lebih rentan terhadap anemia. Saat menstruasi terjadi pengeluaran darah dari dalam tubuh. Hal ini menyebabkan zat besi yang terkandung dalam hemoglobin, salah satu komponen sel darah merah, ikut terbuang melalui darah menstruasi (Hallberg, 2001).

Remaja putri yang berstatus gizi kurus cenderung untuk mengalami anemia sebesar 8.32 kali lebih besar dibandingkan yang berstatus gizi gemuk (OR=8.32; $\mathrm{Cl} 90 \%$ : 2.27-29.15). Penelitian Permaesih dan Herman (2005) juga menunjukkan remaja yang mempunyai IMT kurang (kurus) mempunyai risiko 1.5 kali untuk menjadi anemia. Kelompok wanita usia subur (WUS) yang tidak kurus cenderung tidak menderita anemia (OR=0.60) dibandingkan yang kurus $(\mathrm{IMT}<18.5)$ (Briawan dan Hardinsyah, 2011). Demikian pula penelitian Thompson (2007) menunjukkan bahwa IMT berkorelasi positif dengan kadar hemoglobin yang artinya jika seseorang memiliki IMT kurang maka akan berisiko menderita anemia.

\section{KESIMPULAN}

Faktor risiko anemia pada remaja putri adalah usia pertama menstruasi dan status antropometri. Remaja putri pada kelompok usia 13-15 tahun memiliki kecenderungan mengalami anemia 2.73 kali lebih besar dibandingkan yang berusia 10-12 tahun. Remaja putri yang berstatus gizi kurus cenderung mengalami anemia 8.32 kali lebih besar dibandingkan remaja putri yang berstatus gizi gemuk.

\section{UCAPAN TERIMA KASIH}

Penulis mengucapkan terima kasih dan penghargaan kepada Dinas Kesehatan Kota Bekasi yang telah mengizinkan penggunaan data untuk publikasi bersama.

\section{DAFTAR PUSTAKA}

Angeles-Agdeppa I et al. 1997. Weekly micronutrient supplementation but iron stores in female Indonesian adolescents. Am J Clin Nutr, 66,177-83.

Affandi B. 1990. Gangguan Haid pada Remaja dan Dewasa. FKUI, Jakarta

Beard JL. 2001. Functional consequences of nutritional anemia in adults. dalam Ramakrishnan ed: Nutritional Anemias. CRC Press, USA.

Briawan D et al. 2008. Efikasi suplemen besimultivitamin untuk perbaikan status besi remaja wanita. Gizi Indon, 30(1), 36-46. 
Briawan D, Adriyani A, \& Pusporini. 2009. Determinan keberhasilan program suplementasi zat besi pada siswi sekolah. Jurnal Gizi Klinik Indonesia, 6(2),78-83.

Briawan D \& Hardinsyah. 2010. Risk factors of anemia among child bearing age women 15-45 years in Indonesia. Jurnal Gizi dan Makanan, 33(2), 102-109.

[DEPKES] Departemen Kesehatan. 2001. Pedoman Penanggulangan Anemia Gizi untuk Remaja Putri dan Wanita Usia Subur. Departemen Kesehatan RI, Jakarta.

- 2003. Program Penanggulangan Anemia pada Wanita Usia Subur (WUS). Departemen Kesehatan RI, Jakarta.

2008. Gizi dalam angka. Departemen Kesehatan RI, Jakarta.

Dillon DHS. 2005. Nutritional Health of Indonesian Adolescent Girls: the Role of Riboflavin and Vitamin A on Iron Status [disertasi]. Wageningen University, Netherlands.

Dreyfuss ML, RJ Stoltzfus, JB Shrestha, EK Pradhan, SC LeClerq, SK Khatry, SR Shrestha, J Katz, M Albonico, \& KP West Jr. 2000. Hookworms, Malaria and Vitamin A Deficiency Contribute to Anemia and Iron Deficiency among Pregnant Women in the Plains of Nepal. The Journal Of Nutrition 130, 2527-2536 [8 Maret 2008]

FAO/WHO. 2004. Vitamin and Mineral Requirements in Human Nutrition. $2^{\text {nd }}$ ed. Rome.

Hallberg, L. 2001. Perspectives on nutritional iron deficiency. Annu Rev Nutr, (21):121.

Halterman JS, et al. 2001. Iron deficiency and cognitive achievement among schoolaged children and adolescent in the United States. Pediatric, 107(6),13811386.

Hulu DB. 2004. Faktor-faktor yang mempengaruhi status anemia dan kaitannya dengan prestasi belajar pada siswi SMKN 1 Bogor Skripsi Sarjana Departemen Gizi Masyarakat dan Sumberdaya Keluarga, Fakultas Pertanian, IPB, Bogor.
[INACG] International Nutritional Anemia Consultative Group. 2004. Iron deficiency in early life: challenges and progress. Lima, Peru.

Krummel DA \& Kris-Etherton PM. 1996. Nutrition in women's health. An Aspen, USA.

MOST, USAID Micronutrient Program. 2004. A strategic approach to anemia control program. MOST, USAID, Micronutrient Program, Arlington, Virginia, USA.

Permaesih D \& Herman S. Faktor-faktor yang Mempengaruhi Anemia pada Remaja. Buletin Penelitian Kesehatan 2005, 33(4):162-71.

Ruel MT. 2001. Can Food-Based Strategies Help Reduce Vitamin A and Iron Deficiencies? A Review of Recent Evidence. International Food Policy Research Institute, Washington DC.

Sari M, et al. 2004. Foods naturally rich in iron increase hemoglobin concentration among anemia Indonesian adolescents [Abstract]. Abstract presented at the XXII IVACG meeting and 2004 INACG symposium. 15-17 November 2004. Lima, Peru.

Soekarjo DD, de Pee S, Kusin JA, Schreurs WHP, Schultink W, \& Muhilal, et al. Effectiveness of Weekly Vitamin A (10000 IU) and Iron (60 mg) Supplementation for Adolescent Boys and Girls Through Schools in Rural and Urban East Java, Indonesia. Eur J Clin Nutr, 58(6), 927-37.

Thompson B. 2007. Food-based approaches for combating iron deficiency. Dalam Klaus Kraemer \& Michael B. Zimmermann (Eds.), Nutritional Anemia. Sight and Life Press, Switzerland.

[WHO] World Health Organization. 2001. Iron Deficiency Anaemia, Assessment, Prevention, and Control: A guide for programme managers. World Health Organization, Geneva.

Zhu YI \& Haas JD. 1997. Iron depletion without anemia and physical performance in young women. The Journal of Nutrition, 66, 334-41 [23 Juni 2008]. 